\title{
Mekânsal Planlamada Deprem Riski ve İklim Krizini Birlikte Ele Almak
}

\section{Addressing Earthquake Risk and Climate Crisis together in Spatial Planning}

\author{
Ender Peker, ${ }^{1} \odot$ Ezgi Orhan ${ }^{2}$
}

${ }^{1}$ İngiliz Araştırma Enstitüsü, Ankara

${ }^{2}$ Çankaya Üniversitesi Mimarlık Fakültesi, Şehir ve Bölge Planlama Bölümü, Ankara

\section{ÖZ}

Doğal ve insan eliyle üretilen tehditler karşısında kentlerin korunmasızlığı giderek artmaktadır. Bulundukları coğrafyaya göre kentlerimiz deprem, çı̆̆, heyelan gibi doğal tehlikelerin yanı sıra iklim krizinin tetiklediği aşırı yağış, kentsel taşkınlar, sıcak hava dalgaları ve uzun kuraklıklara maruz kalmaktadır. Bu durum, kentlerin geleceği için beşeri ve doğal sistemlerin bir arada ele alınmasını, ortak stratejiler geliştirilmesini gerekli kılmaktadır. Ancak, Türkiye planlama pratiğinde, iklim değişikliği eylem planı ve deprem stratejisi eylem planı gibi mekânsal planlamayla doğrudan ilişkili olan stratejik belgeler, çoğunlukla birbirinden bağımsız ve planlamadan kopuk olarak üretilmektedir. Bu çalışma, deprem ve iklim konularına duyarlı bir planlama yaklaşımının birlikte kurgulanması gerekliliğini savunmakta ve bu doğrultuda bütüncül bir planlama yaklaşımı ortaya koymaktadır. Bu amaçla, çalışmada öncelikle, deprem ve iklim konularının ülkemizdeki planlamaya ilişkin kanunlarda ve ulusal eylem planlarında nasıl yer bulduğu incelenmiştir. Ardından, Mekânsal Planlar Yapım Yönetmeliği'yle tanımlanan farklı ölçeklerdeki planlar için deprem ve iklim konularının birlikte girdi yapabileceği alanlar tespit edilmiştir. Buradan hareketle, bölge, kent, mahalle ve yapı ölçeklerinde deprem riski ve iklim krizine birlikte yanıt veren planlama stratejileri önerilmiştir. Farklı stratejiler arasındaki olası sinerji ve çatışma alanları tartışılmıştır. Çalışmanın, planlama alanındaki karar vericiler ve uygulayıcılar için mekânsal planlar yapım süreçleri içinde deprem ve iklim değişikliği kaynaklı afetler için bütüncül bir perspektif kazandırması hedeflenmektedir.

Anahtar sözcükler: Afet riski; deprem riski; iklim krizi; mekânsal planlama.

\section{ABSTRACT}

Cities' vulnerability to natural and man-made threats are ever increasing. Cities are under the threat of both natural disasters such as earthquakes, avalanches and landslides; and climatedriven challenges such as excessive precipitation, heatwaves and droughts. This calls for a need of handling natural and human systems together for the future of cities. However, climate and earthquake action plans which naturally present a direct link to spatial planning, are often produced separately in the Turkish planning practice. This study advocates that strategies for combating earthquake and climatic challenges should be harmonized together within the spatial planning system, and respectively, aims at presenting a holistic planning approach. For this purpose, the study first examines the ways in which disaster and climate issues are addressed in the current laws and national action plans. Then, in line with the 'Regulation on the Preparation of Spatial Plans', it examines the spatial planning scales with an aim of determining the potential areas in which disaster and climate issues could be planned together. Taking this as a point of departure, the paper presents a set of planning strategies responding to earthquake risk and climate crisis at regional, city, neighbourhood and building scales. It discusses synergies and conflicts among these strategies at different scales. This study targets to develop a holistic perspective for earthquake and climate change induced disasters, for the decision-makers and practitioners operating in spatial planning processes.

Keywords: Disaster risks; earthquake risks; climate crisis; spatial planning.

Geliş tarihi: 0I.I2.2020 Kabul tarihi: 17.06.202।

Online yayımlanma tarihi: 05.07.202I

İletişim: Ezgi Orhan

e-posta: ezgiorhan@cankaya.edu.tr 


\section{Giriş}

Türkiye kentleri, etkileşimde olduğu doğal ve beşeri tehlikeler nedeniyle farklı düzey ve türlerdeki afet risklerine açık yerleşimlerdir. \%96'sı deprem tehlikesine açık olan ülkemizin yüzölçümünün \%42'si birinci derece deprem bölgesinde bulunmaktadır (AiGM, 1997). Deprem, nüfusun yoğunlaştığı ve kentleşmenin denetimsiz geliştiği yerleşimler için büyük riskler oluşturmaktadır. Öte yandan, bilimsel projeksiyonlar, ülkemizin de içinde yer aldığı Orta Doğu ve Akdeniz coğrafyasında beklenen aşırı sıcakık artışları ve yağıs miktarlarında azalma riskine dikkat çekmektedir (Giorgi ve Lionello, 2008; Lelieveld vd., 20I2). Bu riskler karşısında dirençli olamayan kentlerin sürdürülebilir olmayan kentsel yaşam formları sunmaları kaçınılmaz olmaktadır (IPCC, 2007). Deprem ve iklim risklerine maruz kalan kentlerimizde, kırılganlıkların azaltılması ve sağlıklı kentsel yaşam alanlarının oluşturulması için, bu risklere hazırlıkı olmayı sağlayacak bir planlama yaklaşımına intiyaç duyulmaktadır.

Uluslararası örgütler ve birlikler, bu sorunlarla mücadele ederken, afet kavramını tüm tehlike türlerini kapsayan bir yaklaşımla ele almaktadır. Türkiye afet yönetimi sisteminde ise, afet odaklı yasal ve yönetsel yapı ağırıklı olarak depreme yönelik stratejiler etrafında kümelenmektedir. Ulusal düzeyde, Afet ve Acil Durum Yönetim Başkanlığı (AFAD) tarafından üretilen Ulusal Deprem Stratejisi Eylem Planı (UDSEP), iller düzeyinde ayrıntılandırılmak üzere valiliklere iletilmiştir. Bununla birlikte, yakın geçmişte ulusal iklim değişikliği eylem planları da gündeme gelmiştir. İklim krizi bağlamında, Çevre ve Şehircilik Bakanlığı tarafından İklim Değişikliği Eylem Planı (IDEP) ve İklim Değişikliği Uyum Stratejisi ve Eylem Planı, iklim krizi ile mücadele ve uyum amaçlı hazırlanan ulusal ölçekli planlardır. Deprem ve iklim eylem planlarının iller bazındaki yansımalarına bakıldığında ise, yerel ölçekte bu amaçlarla üretilen planların yaygınlığının düşük olduğu görülmektedir. $\mathrm{Bu}$ durumun temel sebebi, yerel ölçekte hazırlanması ve uygulanması beklenen eylem planlarının belediyeler ve valilikler gibi idarelerin inisiyatifine bırakılmış olmasıdır. Bu kapsamda harekete geçen yerel yönetim ve valiliklerin sayısı çok sınırlı olmakla birlikte, eylem planlarını hazırlayan yönetimlerde ise, planların uygulanmasında sorunlar yaşanmaktadır.

Bu çalışma, hazırlanan eylem planlarının mekânsal planlar yapım süreçlerine entegre edilmesi yoluyla uygulanabileceğini ileri sürmektedir. Çalışma, mekânsal planlama sistemi içinde deprem ve iklim konularının birlikte ele alınması gerekliliğini savunmaktadır. Bu doğrultuda, çalışmanın temel amacı mevzuata girdi yapacak yeni hükümler geliştirmekten ziyade, mevcut yasal çerçeve ve planlama sistemi içinde, mekânsal planlamada bu iki aciliyet taşıyan konunun nasıl birlikte ele alınabileceğini ortaya koymaktır. Afetler, çoklu tehlike türlerinden dolayı toplumun işleyişinde meydana gelen kesintiler olarak tanımlanmakta olup (Balamir, 20ı8; 52), bu çalışmanın odağııı, ülkemizin öncelikli risklerinin başında gelen deprem ve iklim değişikliği kaynaklı afetler oluşturmaktadır.

Ülkemizdeki deprem ve iklim odaklı planlama politikalarının mekânsal planlara entegre edilmesi amacıyla yapılan bu çaıışma, bu iki eylem alanına bütüncül bir yaklaşım geliştirmeyi amaçlamıştır. Bu bağlamda, öncelikle, deprem ve iklim konularına afet riski perspektifinden bakan düzenlemelerin, planlamayı ilgilendiren kanunlarda nasıl yer bulduğu incelenmiştir. 1999 Depreminin gerektirdiği yasal düzenlemeler, 2004 yılında BM İklim Değişikliği Çerçeve Sözleşmesi'ne taraf olunması gibi kırılma noktaları göz önünde bulundurularak, yapılan incelemede 2000 sonrasından günümüze kadar güncellenen kanunlara odaklanılmıştır. Kanunlarla beraber, konular özelindeki ulusal stratejileri ortaya koyan 'Ulusal Deprem Stratejisi ve Eylem Planı', 'Ulusal İklim Değişikliği Eylem Planı' ve 'Ulusal İklim Değişikliği Uyum Stratejisi ve Eylem Planı' belgeleri de incelenmiştir. Her bir planın içinde geliştirilen strateji ve eylemlerden mekânsal planlamayı ilgilendiren konular tespit edilmiştir. Bu tespitler, bölge, kent, mahalle ve yapı ölçeklerinde gruplanmıştır. Buna ek olarak, Mekânsal Planlar Yapım Yönetmeliği'nde tanımlanan planlama kademelerindeki her bir plan türüne ilişkin plan tanımı ve kapsamı incelenerek, ulusal eylem planlarının mekânsal planlamaya işaret eden konuları ile bütünleştirilmiş, deprem riski ve iklim krizi bakımından ortaklaşan ana temalar belirlenmiştir. Sonuç olarak, farklı ölçeklerle ilişkilenen, deprem ve iklim konularını ortak kesen strateji alanları ortaya konulmuştur. Tablo I'de sunulan çerçeveye göre, iklim ve deprem planlamasına yönelik olası ortaklıklar ve çatışma alanları tartışılmışıı.

\section{Ulusal Strateji Belgelerine ve Yasalara Deprem ve İklim Perspektifinden Bakış}

Kent planları, kentler ile iklim krizi arasındaki ilişkinin düzenlenmesindeki ve deprem riskinin azaltılmasındaki rolü ile afet risk yönetiminin önemli bileşenlerindendir. Bu bakımdan, öncelikle, mekânsal planlamayı yönlendiren kanun düzeyindeki yasal düzenlemeler ile deprem ve iklim konuları özelinde hazırlanmış ulusal düzeydeki strateji belgeleri aşağıda özetlenmektedir.

Kentsel planlama bağlamında, son 20 yılda afet risklerini azaltmaya dair hazırlanan yasal düzenlemeler, ağılıklı olarak mekânsal planlama ile kentsel dönüşümü gerçekleştirmeyi amaçlamaktadır. 2005 tarihli 5393 sayılı Belediye Yasasının 73. Maddesinde kentsel dönüşüm yapma yetkisinin belediyelere verildiği görülmektedir. Kanun, deprem risklerine yönelik kentsel dönüşüm yapılabilme yetkisi ve sınırlarını tarif ederken, yerel yönetimlere iklim krizi ile mücadelede aktif bir rol biçmemiştir. 2005 yılında çıkarılan 5366 sayılı Yıpranan Tarihi ve Kültürel Varlıkların Yenilenerek Korunması ve Yaşatılarak Kullanılması hakkında Kanun ile sit alanlarında kentsel dönüşüm ve yenileme olanaklı kılmış ve yetki belediyelere verilmiş- 


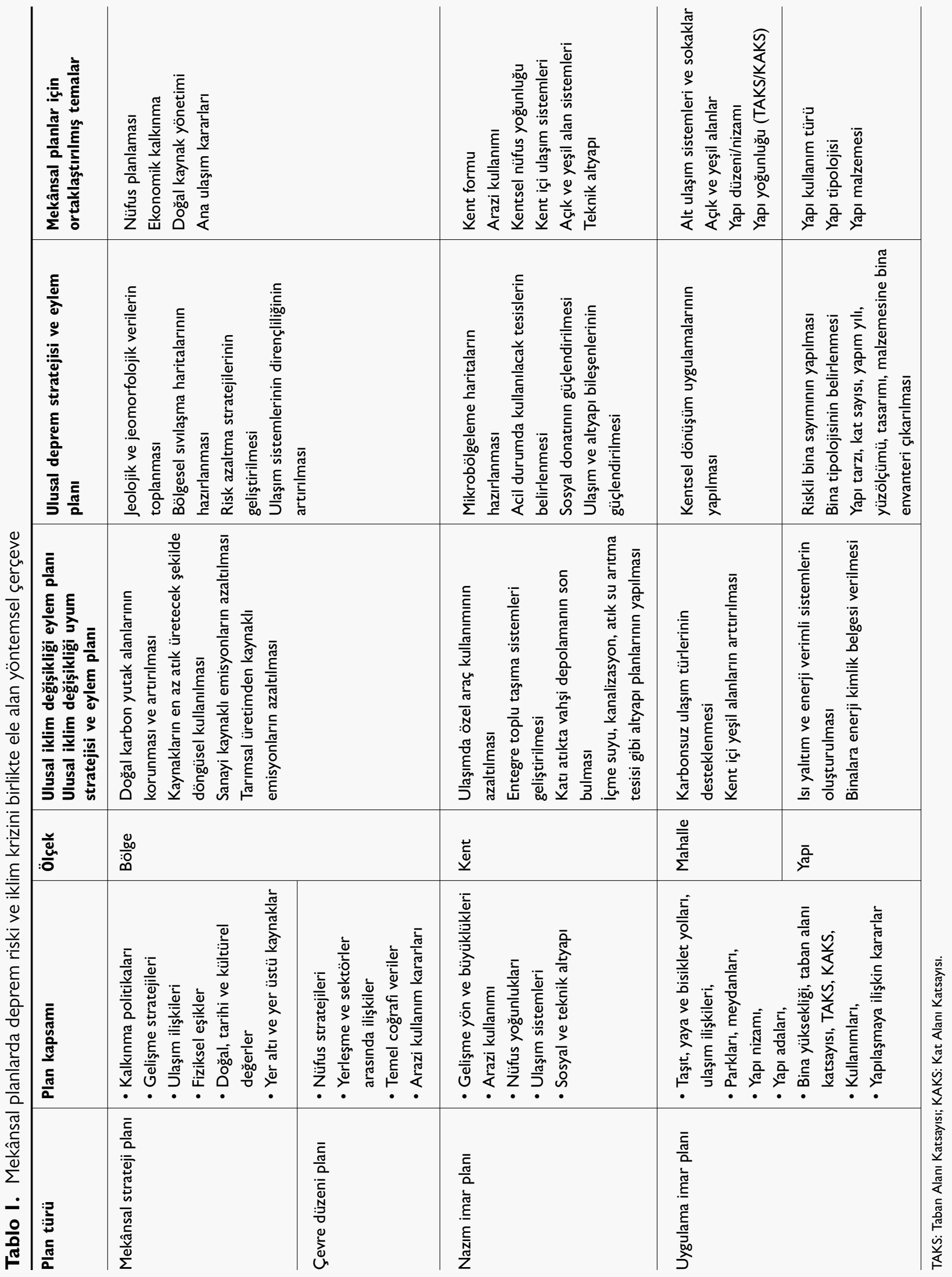


tir. Yasada deprem veya iklim risklerine doğrudan bir referans olmamakla birlikte, belediyelere muğlak bir afet riski azaltma sorumluluğu tanımlanmıştır. Kentsel planlamada, afetlere yönelik en tanımlı yasa olan 6306 sayılı Afet Riski Altındaki Alanların Dönüştürülmesi Hakkında Kanun, 2012 yılında yürürlüğe girmiştir. Bu kanunla birlikte Çevre ve Şehircilik Bakanlığı riskli alanlarda plan yapma, yaptırma ve onaylamada yetkili idare olarak tanımlanmıştır. Kanun, riskli alanlarda sağlıklı ve güvenli yaşam çevresi oluşturulması hedefi taşıyan bir kentsel dönüşüm yasası niteliğindedir. Riskli alan ve yapı vurgusu kentlerin taşıdığı afet risklerini bütüncül olarak ele almaya zemin hazırlamaktadır. Kanun iklim değişikliği bağlamında değerlendirildiğinde ise, Bakanlığın yapılarda enerji verimliliğini arttırıcı düzenlemeleri yapma yetkisine sahip olduğu görülmektedir. Bu yasa, yetkiyi merkezi yönetim elinde toplayarak iklim değişikliğine uyum ve deprem gibi yere özgü planlama gerektiren konuları yerelden uzaklaştırmakta ve yasayla birlikte, alt ölçekli planlamada yerel yönetimlerin devre dışı kalarak tek tip çözümlerin üretilmesi riski gündeme gelmektedir. Son olarak, 3194 sayılı İmar Kanunu'nun deprem ve iklim konularına dokunan maddelerine bakıldığında, 2013 yılında yürürlüğe giren Madde $8 / \mathrm{H}$ bendinde; köylerde ve kırsal özellik gösteren diğer yerleşmelerde enerji verimli, iklim duyarlı ve ekolojik özellikli plan ve projeleri hazırlama yetkisi yine Bakanlığa verilmiştir. Bu ibareyle, imar kanununun iklim konusuna yaklaşımının kırsal yerleşimlerle sınırlı olduğu ve kentsel alanda kapsayıcı olmadığı görülmektedir. Benzer şekilde, deprem konusunda da 2018 yılında yürürlüğe giren geçici 16. Madde'de, afet risklerine hazırlık kapsamında ruhsatsız veya ruhsat ve eklerine aykırı yapılar için yapı kayıt belgesi verilebileceği belirtilmektedir. Bu madde ile, riskli bölgelerdeki yapılar veya riskli yapılar kayıtlı ve kullanılabilir hale gelmektedir. Böylelikle, 6306 sayılı yasanın amaçladığı afet riskli alanların dönüşümü hedefiyle çelişen durumların ortaya çıkması muhtemel görünmektedir.

Bu değerlendirme çerçevesinde, güncel mevzuatta her ne kadar afet risk azaltma vurgusu yer alsa da, deprem ve iklim konularını işaret eden maddelerin bütünleşik ve kent ölçeğinde bir planlama yaklaşımı geliştirmediği, temel müdahale aracı olarak yapı ölçeği veya mahalle ölçeğinde kentsel dönüşümün işaret edildiği kısıtlı bir çerçevede kaldığı görülmektedir. Ayrıca, yasalarda, ağırıklı olarak kentsel dönüşüm ile depreme dirençli yapılaşma hedefi tanımlanırken, enerji verimliliği, düşük karbonlu yapılaşma gibi iklim krizi ile doğrudan ilişkili konulara yer verilmediği görülmektedir.

Afet yönetim yaklaşımının genel çerçevesini belirleyen mevzuatın yanı sıra, ulusal ölçekte hazırlanmış ve afet risklerini azaltmayı hedefleyerek planlamayı yönlendiren veya bağlayıcı olan diğer belgeler de bulunmaktadır. Ulusal ölçekte hazırlanmış eylem planları, merkezi ve yerel yönetimlerin genel olarak yetki ve sorumluluk alanları ile rollerini tarif eden belgelerdir.
Ulusal Deprem Stratejisi ve Eylem Planı (UDSEP), 20122023 eylem dönemi için hazırlanmış ve depremlerin neden olabilecekleri fiziksel, ekonomik, sosyal, çevresel ve politik zarar ve kayıpları önlemek ve etkilerini azaltmak ve depreme dirençli, güvenli, hazırlıklı ve sürdürülebilir yeni yaşam çevreleri oluşturmayı amaçlamıştır (AFAD, 20I I). UDSEP'in amaçları üç ana eksende gruplandırılmıştır. Bu çalışmada, UDSEP'in “deprem güvenli yerleşme ve yapılaşma” eksenine odaklanılmaktadır. Bu eksendeki stratejilere göre, yerleşimlere ilişkin jeolojik ve jeomorfolojik verilerin toplanması, bölgesel sıvılaşma haritalarının hazırlanması gibi zemin çalışmaları ile elde edilen mikro bölgeleme haritalarının mekânsal planlamaya girdi sağlaması hedeflenmiştir. Diğer yandan, yapılara ilişkin tespit ve sayımlarla kırılgan ve dayanıksız yapı stokunun risk dereceleri belirlenerek güçlendirme yapılması ve gerekli alanlarda kentsel dönüşüm ile müdahale edilmesi önerilmiştir. Benzer şekilde, ulaşım ve altyapı bileşenlerinin deprem risklerinin belirlenmesi ve bunların güvenli hale getirilmesi önerisi sunulmuştur. Ek olarak, sosyal donatıların ve sağık tesislerinin güçlendirilmesi ve acil durumda kullanılacak olanların belirlenmesi hedefi ortaya konulmuştur. Plan, deprem güvenli yerleşme ve depreme dayanıklı yapılaşmanın sağlanması için, AFAD başta olmak üzere, merkezi idarenin, yerel yönetimlerin ve diğer aktörlerin rol ve görevlerini tanımlayarak bu kurumları göreve çağırmaktadır. Planda, deprem risklerinin azaltılmasına yönelik teknik, fiziksel, mekânsal, eğitsel, sosyal ve yasal stratejiler geniş bir yelpazede sunulmakla birlikte, dirençli kentleşmenin sağlanması için temel adımların nasıl hayata geçirileceği ve denetleneceği konuları belirsiz kalmıştır.

UDSEP ile benzer şekilde, Ulusal İklim Değişikliği Eylem Planı (IDEP) ve Ulusal İklim Değişikliği Uyum Stratejisi ve Eylem Planlarında (IDUSEP) da iklim değişikliği ile mücadelede temel hedeflerin tanımlandığı ve bunları takip eden stratejik düzeyde plan bilgisinin üretildiği görülmektedir. IDEP, sektörel bir yaklaşım izleyerek, kentlerde enerji, bina, sanayi, ulaşım ve atık gibi farklı sektörlerde iklim duyarlı hedefler ortaya koymaktadır. Enerji sektöründe, enerji verimliliğinin artırılması ve yenilenebilir enerji kaynaklarının kullanımı; bina sektöründe, ısı yalıtım ve enerji verimli sistemlerin oluşturulması; sanayide sera gazı emisyonlarının sınırlandırılması; ulaşımda alternatif ve temiz taşıma sistemlerinin geliştirilmesi; tarımda karbon stok miktarının artırılması, atık sektöründe vahşi depolamaya son verilmesi ve bertaraf tesislerinin kurulması öne çıkan sektörel odaklar olarak tarif edilmiştir. IDEP'te açıkça belirtilmemiş olsa da, tüm bu konular kentlerin oluşum ve gelişiminde temel rol oynayan mekânsal plan kararları ile doğrudan ilişkilidir. Diğer taraftan, iklim değişikliğinden etkilenme boyutuna odaklanan IDUSEP de değişen koşullara uyum konusunda temel eksenler ve stratejiler sunmaktadır. Uyum bağlamında, kentsel su yönetiminin yeniden planlanması; kentsel altyapının içme 
suyu, kanalizasyon ve atık su kapsamında yenilenmesi; iklim değişikliğinin etkilerine karşı, korunan alanlar, deniz ve kıyı alanları ve orman alanlarındaki türlerin korunması; tarımsal su kullanımının sürdürülebilir bir şekilde planlaması; toprak ve tarımsal biyolojik çeşitliliğin korunması hedefleri etrafında öneriler geliştirilmiştir.

Deprem ve iklim özelinde hazırlanan ulusal eylem planlarının, mekânsal planlamanın farklı ölçek ve konularını ilgilendiren içeriklere sahip olduğu görülmektedir. Ancak, bu planlarda tanımlanmış stratejilerin soyut düzeyde kalması, eylem adımlarının ve uygulama yöntem ve araçlarının belirsizliğine yol açmaktadır. Öte yandan, her iki ulusal düzeydeki eylem planında 'sorumlu kuruluşlar' merkezi yönetim organları olarak ortaya konulurken, yerel yönetimler 'ilgili kuruluşlar' başlığı altında belirsiz bir rol ile tanımlanmıştır. Afetler, temelde yereli etkileyen olgular olduğu için, bu belgelerde yerel yönetimlerin sorumluluk ve yetkilerinin detaylandırılmış olması beklenir. Ancak, doğrudan rol tanımı bulunmayan yerel yönetimler, etkin yerel eylemlerin hayata geçirilmesini inisiyatifler üzerinden yürütmektedir. Yasal zorunluluğun olmaması nedeniyle, kendi yetki alanı sınırlarında deprem veya iklim eylem planı üreten yerel yönetimlerin sayısı oldukça düşüktür. Yerel eylem planının hazırlanmasından bağımsız, iki konunun da dikkate alınarak kentsel risklerin azaltılması, süregelen mekânsal planlar yapım süreçlerinde alınacak plan kararlarıyla sağlanabilir. Mekânsal planlamayı yönlendiren stratejik belgelerden biri olan Bütünleşik Kentsel Gelişme Stratejisi ve Eylem Planı (KENTGES 20I0-2023) da bu yaklaşımı savunur. KENTGES her ne kadar deprem ve iklim konularının birlikte ele alınmasına dair bir vurgu yapmasa da, deprem risklerine ve iklim değişikliğinin olumsuz etkilerine karşı alınacak tedbirlerin, mekânsal planlama sistemi ile bütünleştirilmesini işaret eder (ÇŞB, 20l0). Buradan hareketle, bu çalışma, deprem ve iklim konularının mekânsal planlama sistemi içinde ve bir arada ele alınabileceğini ileri sürmektedir.

\section{Mekânsal Planlarda Deprem ve İklimi Birlikte Ele Almak}

Deprem ve iklim değişikliği konularını yönetmek amacıyla hazırlanan ulusal eylem planları, soyut stratejiler geliştirmekle birlikte yerel risklerle başa çıkabilecek araç ve yöntemleri sunmamaktadır. Ancak, mevcut mevzuat çerçevesinde kalarak ve ulusal eylem planlarının stratejileri doğrultusunda, mekânsal planlama yoluyla deprem ve iklim krizi ile ilişkili riskleri azaltacak politikalar geliştirmek mümkündür. Bunu yaparken, her iki konu kapsamında ortaklık gösterecek alanlar olabileceği gibi, çatışma alanları da doğabilir. Bu çalışma, Mekânsal Planlar Yapım Yönetmeliği'nin sunduğu çerçeveye bağı kalarak, her bir planın ölçeği ve kapsamı doğrultusunda iklim krizine cevap verirken aynı zamanda deprem risklerini azaltabilecek strateji alanlarını dört ölçekte kümelemektedir.

\section{I. Bölge Ölçeği Kapsamındaki Strateji Alanları}

\section{I.I. Nüfus Planlaması}

Dengeli nüfus dağılımı, nüfusun belirli bölgeler veya kentlerde yığılmasını engellemek açısından önemlidir. Mega kentler barındırdıkları nüfus yoğunluğu nedeniyle deprem ve iklim açısından daha büyük risk havuzlarıdır. Örneğin, İstanbul, Jakarta, Dhaka, Mexicocity, Delhi ve Mumbai gibi bulundukları ülkeye göre dengesiz bir oranda nüfusa ev sahipliği yapan metropoller, afet riskleri açısından en korunmasız görülen yerleşimlerdir (Wisner, 2003). Bu kentlerde, artan nüfusu barındırmak için yeni yerleşim alanlarının açılması, genellikle sulak alanlar, akarsular ve fay hatları gibi kritik bölgelere yaklaşılmasıyla sonuçlanmaktadır. Etkilenecek nüfusu azaltmak için, nüfus planlaması aracılığıla iklim krizi ve deprem risklerini önceliklendiren üst ölçek planlama kararları alınması gerekmektedir. Dengeli nüfus planlaması ile, sınırlı kaynaklara sahip metropoliten kentlerde su, gıda ve enerji tüketimini azaltmak mümkündür (Faisal and Parveen, 2004).

\section{I.2. Ekonomik Kalkınma}

Ulusal düzeyde istihdamı barındıran, tarım, sanayi ve hizmet sektörlerinin bölgeler arası eşitsizliği giderecek şekilde planlanması gerekmektedir. İstihdam amaçlı kentler arası göçü engelleyici yerel kalkınma dinamiklerinin belirlenmesi ve yerel ekonomik kalkınma modellerinin tasarlanması üst ölçek planların odağı olmalıdır. Tarım sektörü açısından, tarım alanlarının korunması, tarım istihdamının kırsal alanda tutulması ve tarımsal üretim biçiminin iklim krizine cevap verebilir hale getirilmesi gerekmektedir. Bunun için, vahşi sulamadan kaçınılması, damla sulama sisteminin teşvik edilmesi ve yerel iklim ve toprak koşullarına uygun tohumların seçilmesi gibi stratejiler, doğal kaynakların verimli kullanımı açısından iklim duyarlı tarımsal üretime katkı sağlayacaktır.

Sanayi açısından bakıldığında, sanayi kuruluşlarının ulusal düzeyde kalkınma yaratacak dengeli bir dağılıma sahip olması beklenir. Bunların tek bir odakta toplanması büyük nüfus yı̆̆ılmalarına yol açacaktır. Örneğin, 1999 Marmara Depremi'nin bu denli ağır yıkıcı etkilere yol açmasının nedenlerinden biri, ülkenin en sanayileşmiş ve nüfusu en kalabalık bölgesinde meydana gelmiş olmasıdır (Orhan, 2016). Aynı zamanda, sanayinin belirli bölgelerde yığılması, karbon salımı, yüksek enerji tüketimi ve hava kirliliği açısından bu bölgelerde olumsuz yaşam koşulları yaratacaktır.

Kentsel ekonomik kalkınmanın tek sektöre dayalı olması da kentlerde ekonomik kırılganlığı arttıran etkenlerdendir. Örneğin, başat sektörü turizm olan kentlerde, bu sektörlerin olası bir afet sonrası kesintiye uğraması, kentin ekonomik dinamosunun çökmesine neden olacaktır. Böyle bir senaryoda, kentsel ekonomiyi ayakta tutacak sektörel çeşitliliğin bölge ölçeğinde planlanması gerekmektedir (Xiao 
ve Drucker, 20I3). Söz gelimi, kış turizminin baskın olduğu Erzurum kentinde olası sıcaklık artışları ve kar kalınlıklarının düşmesi halinde, bu sektörün devamlılığının sağlanamaması riski uzun devreli planlarda dikkat edilmesi gereken bir konudur. Bu doğrultuda, üst ölçek planlarda alternatif ekonomik sektörlerin düşünülmesi ve mekânsal planlarla desteklenmesi gerekir.

\section{I.3. Doğal Kaynak Yönetimi}

Kentin sahip olduğu doğal kaynaklar ve doğal çevrelere göre nüfus taşıma kapasitesi ve yerleşim alanı sınırları belirlenmelidir. Su kaynakları, havzalar, sulak alanlar, ormanlar, tarım arazileri, meralar gibi limitli doğal kaynakların gelecek kuşaklara aktarılması için kentsel gelişmenin sınırlarının ve doğal eşiklerin bilimsel yöntemlerle çizilmesi gerekmektedir. İklim krizinin tetiklediği kuraklık riski ve bunun kırsal alan üzerindeki etkileri dikkate alındığında, su kaynaklarının korunması özellikle tarımsal faaliyetlerin sürdürülebilirliği ve gıda güvenliği açısından önem kazanmaktadır (Turral vd., 20I I). Kırsal alan ve su kaynaklarının korunmasının yanı sıra, kentin büyümesinin kontrol edilmesinde, zemin sıvılaşmasının yüksek ve toprak taşıma kabiliyetinin düşük olduğu alanlar deprem riskleri açısından eşik olarak kabul edilmeli ve yerleşilemez alanlar olarak tanımlanmalıdır (Berke vd., 1989).

\section{I.4. Ana Ulaşım Kararları}

Bölge planlama ölçeğinde, kentler arası erişilebilirliği sağlamak için alternatif ulaşım bağlantıları sunan, çevre ve iklim dostu ulaşım türleri tercih edilmelidir. Olası bir afet durumunda, kesintisiz erişilebilirlik sağlamak için kentleri bağlayan alternatif ulaşım türlerinin planlanması önemlidir. Tek tür ulaşıma sahip kentlerde olası kriz ortamında ulaşımda kesintinin olması riskleri arttıracaktır. Örneğin, 1999 Depreminde karayolu ağırlıklı erişime sahip olan Sakarya'nın çevresel bağlantı yollarındaki viyadüklerin çökmesi kente ulaştırılacak yardımları büyük ölçüde sekteye uğratmıştır (Erdik, 2000). $\mathrm{Bu}$ gibi sorunların giderilmesi için demir, deniz ve havayolu bağlantılı taşımacılı̆ıı devreye girmesi deprem koşullarında oldukça önemlidir. Ancak, iklim değişikliği açısından bakıldığında, havayolu gibi karbon salımını yüksek oranda arttıracak ulaşım türlerinin her kentte yer alması deprem ve iklim krizinin birlikte planlanmasında çatışma yaratacak bir stratejidir. Ülkemizde yolcu potansiyelinin düşük olduğu küçük ve orta ölçekli kentlerde havaalanlarının açılması, hava taşımacılığına yönelen yolcu sayısını arttırarak karbon emisyonlarının doğrudan artmasına sebep olmaktadır (Elbir, 2008; Keskin, 2006). Dolayısıyla havaalanları yapım ve yer seçim kararları alınırken, sadece erişilebilirlik kıstası değil, kentin coğrafı koşulları, nüfusu, barındırdığı alternatif ulaşım modları, kentin temel ekonomik sektörünün yarattığı mobilite yoğunluğu ve arazi kullanımı gibi birçok değişken bir arada analiz edilmelidir. Bu çok değişkenli analiz, sadece havaalanları için değil tüm ulaşım türleri için geçerlidir.

\subsection{Kent Ölçeği Kapsamındaki Strateji Alanları}

\subsection{Kent Formu}

Üst ölçekte kent formu, kentin gelişme yönü, ulaşım ve altyapı sistemleri, arazi kullanımının dağııımı gibi kentin birçok alt sistemini etkilemektedir. Kent formunun saçaklanması veya kompakt olması deprem ve iklim açısından farklı etkilenme biçimleri doğurmaktadır. Saçaklanmış bir kent formunda, kentsel alanların doğal alanları tahrip ederek büyümesi, birbirinden kopuk, düşük yoğunluklu çalışma ve yaşama alanlarının açılması, alt yapı maliyetlerinin artması, toplu taşım kullanımının azalması ve beraberinde özel araç odaklı kentsel dolaşımın artması gibi problemler doğması olasıdır (Andong ve Sajor, 2017; Marcshall, 2008; Trubka vd., 2010). Kent parçaları arasında artan mesafeler, buna bağlı ulaşım uzunluklarını ve dolayısıyla fosil yakıt bağımlı̆̆ı, enerji tüketimi ve karbon salımını arttıracaktır. Deprem riskleri açısından ise saçaklanan bir kentte kriz ortamında müdahalede bulunmak ve kaynak dağıtımını yürütmek güçleşecektir (Burby vd., 1999). Saçaklanarak büyüyen düşük yoğunluklu bir yerleşimde depremin yaratacağı riskin azalması söz konusu olabilir. Özellikle, az katlı yapılaşmanın olduğu yerleşim yerlerinde can kaybı oranının da düşük olması beklenir. Dolayısıyla, iklim krizi açısından, saçaklanmış düşük yoğunluklu bir kentsel büyüme karbon salımını artırııı koşullar yaratırken, deprem bakımdan riskleri azaltıı bir etki yapabileceğinden iki alan arasındaki çatışma konularından bir haline gelebilir.

Saçaklanmış forma alternatif olarak geliştirilebilecek kompakt kent formu ile bahsi geçen problemlerin aşılmasını sağlayacak bir kentsel düzen yaratmak mümkündür. Kompakt form, hizmetlerin kolay dağııııını ve eşit erişilebilirlik imkanı sunması açısından deprem risklerini azaltan bir kent dokusu oluşturabilir. Bu form, aynı zamanda ısınma ve soğutma için kullanılan enerjinin, kent içinde kullanılan enerji ve altyapı maliyetlerinin azalmasını da sağlayacaktır. Ancak kompakt form, dar bir coğrafyada dikey büyüyen yüksek katlı yapılardan oluşan yoğun bir yapılaşma olarak düşünülmemelidir (Peker ve Aydın, 2019). Çünkü böylesi bir doku, yüksek yapılaşma yoğunluğu, trafik sıkışıklı̆ı ve beraberinde emisyon artışını tetikleyeceği için iklim ve deprem açısından olumsuz bir durum oluşturacaktır.

Yeni yerleşim alanlarının tasarımında görece daha kolay izlenebilecek kompaktlık ilkesinin, kentleşme tarihi uzun yıllar öncesine dayanan ve halihazırda saçaklanmış kentlerde uygulanması kolay olmayacaktır. Örneğin, İstanbul gibi metropoliten bir kentte, mevcut kent formunu kompakt forma dönüştürmek kolay uygulanabilir bir strateji değildir. Yüksek nüfusa sahip mega kentlerde, topografya ve zemin koşulları göz önünde bulundurularak, yeni kompakt alt odaklar ya da koridorlar yaratarak kent formuna müdahale edilebilir. Yeni odakların kendi kendine yeten, karma kullanımlar içeren, kompakt ve sürdürülebilir alt odaklar olması saçaklanan kent formunda yaşanan problemlerin çözülmesini sağlayabilir. 


\subsubsection{Arazi Kullanımı}

Kentin bütününe veya bir parçasına odaklanan Nazım İmar Planları konut, ticaret, sanayi, turizm, hizmet, idari, eğitim, sağlık vb. kullanımların yer seçimlerini, alan büyüklüklerini ve kullanımların birbirleriyle ve çevreleriyle uygunluğuna dair kararları içerir. Kullanımların yer seçimi ve arazi kullanımları iklim ve deprem açısından farklı boyutlarda riskler doğurabilir. Konut ve çalışma alanları arasındaki uzun mesafeler, kent içi ulaşımda karbon emisyonlarının artmasına sebep olan günlük iş yolculuklarının süresini ve sıklığını artıracaktır (Mitchell vd., 20I I). Benzer şekilde, konut alanlarının sağlık, itfaiye, depolama alanları gibi kritik tesislere yakın ve kolay erişilebilir olması, deprem sonrasında müdahaleyi hızlandıracaktır (Balamir, 2018). Buna ek olarak, afet müdahalesinde rolü olan kritik tesislerin kentin her bir alt merkezine dengeli dağılması, kent bütününde etkin hizmet vermeyi sağlayacaktır. Bu bakımlardan, karma arazi kullanımının kentin alt bölgeleri için desteklenmesi gereken bir strateji olduğu ileri sürülebilir.

Kentsel bir kullanımın yer seçimi, çevresindeki kullanımlarda bir aksaklık ya da tehdit oluşturmayacak şekilde mevcut kullanımların niteliğine uygun yapılmalıdır (Burby ve Dalton, 1994). Örneğin, büyük sanayi alanlarının yer seçimi yapılırken sanayi kaynaklı emisyonlar ve beraberinde oluşacak hava kirliliğinin yaşam bölgelerine taşınmasını engelleyici tampon bölgeler tasarlanmalıdır. Benzer şekilde deprem riskleri için de, yaşam çevrelerinin güvenliği açısından yanıcı, patlayıcı ve tehlikeli madde içeren kullanımların komşuluklarında uygun yaklaşma mesafeleri gözetilmelidir. Kullanımlar arasındaki ilişkiler ve mesafeler, kent formu başlığı altında tartışılan kompaktlık ilkesi ışı̆̆ında kurgulanmalıdır.

\subsubsection{Kentsel Nüfus Yoğunluğu}

Kent içinde dengeli nüfus dağılımı, nüfusun belirli alt bölgeler veya mahallerde birikmesini engellemek ve bu alanlarda adil kentsel hizmetler sunmak açısından önemlidir. Ulaşım, teknik altyapı, sağlık gibi temel kamusal hizmetler, özellikle alt gelir gruplarının yaşadığı yoksul mahallelerdeki demografik ve sosyal nitelikler göz önünde bulundurularak sunulmalıdır. Çünkü bu gruplar afet riskleri açısından en korunmasız sosyal bileşenlerdir (Blaikie vd., 2014). İklim ve deprem açısından, kamusal hizmetler nüfusun büyüklüğüne, erişilebilirliğe, kullanımlar arası uygunluğa göre yerleştirilmelidir. Riskin yüksek olduğu yerleşimlerde, eğitim ve sağlık gibi tesislerin sayısı ve büyüklügünün ortalama planlama standartların üzerinde olması, olası bir deprem durumunda etkilenen nüfusun bir araya gelip bu noktalardan hizmet alabilmesi için etkin bir strateji olacaktır. Nüfus büyüklügünün kentsel yaşamın temel gereksinimlerini oluşturan su ve gıda talebi ile doğrudan ilişkili olduğu düşünüldüğünde, tüketim ihtiyaçları ve ekonomik kaynakların birlikte kurgulandığı bir nüfus planlaması iklim krizi bağlamında önem kazanmaktadır (Vörösmarty vd., 2000).

\subsubsection{Kent Iç̧i Ulaşım Sistemleri}

Kentsel ulaşım sistemleri, makroform ve kentsel arazi kullanımları ile bir bütündür ve kentin tamamını kapsayan nazım plan kararlarında şekillendirilir. Kentsel mekânın biçimlenişi, arazi kullanımları ve yoğunluk dağılımı ulaşım sistemi ile birlikte çözülmesi gereken alanlardır. Bu şekilde, kentsel saçaklanmayı önleyen ve kompakt kent formlarını destekleyen sürdürülebilir bir kentsel ulaşım sistemi elde edilebilir. Alternatif ve entegre ulaşım sistemleri kompakt kent formunun omurgasını oluşturabilir; böylece karbon salımını azaltmak ve deprem risklerini paylaşmak mümkün olacaktır. Mevcut durumda karayolu odaklı ulaşım sistemlerine sahip kentlerin, raylı sistemler, motorsuz ulaşım sistemleri ve deniz taşımacılığı gibi diğer türlerle desteklenmesi ve bu türlerin birbirleri ile entegre edilmesi gerekmektedir. Motorize taşıt odaklı kentsel ulaşım sistemleri, kentleşme kaynaklı karbon emisyonunun en temel nedenlerinden biridir. Özellikle artan özel araç kullanımı, yaygın toplu taşıma ağının ve altyapısının olmaması kentsel ısı adası oluşumuna ve atık ısı salımına neden olur (Stone vd., 20I0). Motorsuz ulaşım türlerinin yaygınlaştırılması ve özellikle bisikletin kentsel ulaşım payında yer bulacak ölçüde yaygın kullanılan bir ulaşım türüne dönüştürülmesi ve güvenli sürüş için uygun altyapının geliştirilmesi karbon azaltım stratejilerinden bazılarıdır. Benzer şekilde, farklı türlerle çeşitlendirilmiş kent içi ulaşım ağı, sistemlerden birinde meydana gelecek aksamanın diğerleri tarafından kompanse edilmesine ve deprem sırasında ve sonrasında erişilebilirliğin devam etmesine katkı sağlayacaktır. Bu açıdan, karayolu sistemlerinin raylı sistemler ve yaya dolaşımlarıyla desteklenmesi gerekir. Çoklu tehlike türleri göz önüne alındı̆̆ında, hiyerarşik bir yol sistemi kurgusunun üretilmesi ve yolların sürekliliğinin olması önemlidir. Aynı zamanda, yol güzergahları ve genişliklerinin bu hiyerarşik yapıya uygun olması beklenir.

\subsubsection{Açık ve Yeşil Alan Sistemleri}

Kentsel yeşil altyapı elemanları olan vadiler, dereler, kıyılar, orman alanları gibi doğal nitelikli açık ve yeşil alanlar, planlama yoluyla yeşil sistem oluşturacak ve ekosistemin sürekliliğine hizmet edecek şekilde ele alınmalıdır (Gedikli, 2020). Aynı zamanda, bu kentsel yeşil altyapı elemanları iklim ve deprem riskleri ile mücadele edecek şekilde işlev kazandırılarak planlanmalıdır. Bu alanlar, su geçirgenliği, karbon emilimi gücü ve taşkın yönetimindeki rolleri ile iklim değişikliğine adaptasyon açısından avantaj sağlarken; deprem açısından kentsel yerleşilebilir alanların belirlenmesinde eşikleri oluşturur. Kentsel yapılı çevre içerisinde, açık ve yeşil alanların dağılımı Nazım İmar Planlarında afet konuları gözetilerek uygun standart ve büyüklüklerde üretilmelidir. Kent bütününde, açı alanların hiyerarşik bir örüntüye sahip olması ve kentin alt birimlerine bağlanacak şekilde (ör: Kent, semt, mahalle vb.) tasarlanması gereklidir. Bu açık alanlar, kentte farklı işlevleri yerine getirecek esnekliğe sahip olmalıdır. Açık alanlar kent ölçeğinde hava koridorları oluşturmak amaçlı tasarlanabileceği gibi, mahalle ölçeğinde toplanma alanı rolü de üstlenebilir. 
Kentsel tasarım perspektifinden bakıldığında, açık ve yeşil alanlar yapılı çevrede dolu-boş alan dengesinin sağlanması için birer araçtır. Kent parçalarına dengeli dağılan, orta ve küçük ölçekli yeşil ve açık alanlar için, iklim ve deprem açısından sinerji yaratan stratejiler geliştirilebilir. Örneğin, bu alanlar kentte su geçiren yüzeyleri arttırırken, deprem sonrasında toplanma amaçlı da kullanılabilir. Benzer şekilde, bu alanlar, kentlilerin acil durum ortamında bir araya gelme mekânları, yardımların dağıtım noktaları ve bilgi edinme merkezleri olarak işlev görecektir. Acil durumda toplanma amacıyla tasarlanan açık alanların insan, mal, hizmet ve bilgi akışının sağlanabileceği kapalı alanlarla desteklenmesi, uygun büyüklüklerde olması, alternatif yollarla erişilebilir olması ve merkezi bir alanda konumlanması gerekir (French vd.,2019). İklim açısından bakıldığında, açık ve yeşil alanların yarattığı mikroklimatik etki kentsel yaşamda termal konforun sağlanmasında önemli rol oynayacaktır (Peker, 202I). Bu noktada, kent için üretilecek yeşil stratejiler ile gölgelendirme yapma, yutak alan oluşturma, kentsel taşkın riskini engelleme, yürünebilirliği arttırma gibi amaçlara ulaşmak mümkündür. Açık ve yeşil alanlar tasarlanırken, mevsimsel etkiler göz önünde bulundurularak, ağaçlandırma, gölgelikler ve su elemanı gibi peyzaj elemanları bir arada düşünülmelidir (Littlefair, 2000). Örneğin, karasal iklimin hakim olduğu kentlerde, yüksek yaz sıcaklıklarında yaya konforuna katkı sağlayacak geniş yapraklı, gölge veren ağaç türleri arasından; kış mevsimindeki güneşten yararlanma ihtiyacı gözetilerek, yaprak döken türler tercih edilmelidir (ör: Akçaağaç, Çınar). Böyle bir yaklaşım, termal konforun sürekliliğini sağlayarak kentte yürünebilirliği teşvik edecektir.

\subsubsection{Teknik Altyap}

Su, atık, enerji ve haberleşme istasyonları ve ağlarından oluşan teknik altyapı, kent bütününü ve alt kent parçalarını düzenleyen nazım planlarının temel unsurlarındandır. Yaşamsal öneme sahip su kaynaklarının yönetimi kentsel planlamanın önemli bir parçasıdır. İçme suyu, sulama, atık su ve drenaj sistemleri sürdürülebilir su yönetimi yaklaşımının bileşenleridir. Değişen iklim koşullarında, nüfus artışı, doğal kaynakların tahribatı ve sosyo-ekonomik faktörlerle birlikte suyun temini kentler için günümüzde ciddi bir tehdit oluşturmaktadır. Öyle ki, İstanbul içme suyu kaynağının Düzce'deki Melen Çayı'ndan, Ankara'nın ise Kızılırmak'tan taşınması, sorunun boyutunun kent ölçeğinden bölgesel ölçeğe geçtiğinin göstergesidir. Benzer şekilde, artan sıcaklıklar ve kuraklık tehditleri, yoğun tarımsal faaliyetlerin sürdürüldüğü kırsal alanlarda üretim amaçlı sulama ihtiyacı açısından risk oluşturmaktadır. Bu nedenlerle, yerel ölçekte su yönetimi uyum stratejileri, iklim değişikliğinin yerelde tetikleyeceği riskleri gözeterek kurgulanmalıdır. Sudan yoksun kalmanın yanı sıra, bazı coğrafyalarda düzensiz yağışlardan dolayı kentsel alanların aşırı suya maruz kalması gibi riskler de doğacaktır. Bu noktada, ani ve düzensiz yağışlardan kaynaklanan kentsel sel riskini engellemek için yağmur suyunun drenajını kolaylaştıracak kentsel açık alanlar ve bunu destekle- yen teknik altyapının birlikte kurgulanması önemlidir. Deprem açısından ise, su şebekelerindeki olası kesintiler kentsel yaşam fonksiyonlarının durmasına yol açabilecek riskler taşımaktadır (Orhan, 20I4). İçme suyu ve kanalizasyon şebekelerinin kesintiye uğraması veya deprem sırasında zarar görmesi afetzedeler için temiz su sağlama probleminin doğmasına ve salgın hastaııkların oluşmasına yol açabilecektir.

Atık sistemleri, farklı kullanımlardan doğan (ör: Evsel, sanayi, tarım vb.) katı atıkların yönetimini içeren konular olup, kent ölçeğinde mekânsal planlarda çözümlenir. Yakın zamana kadar vahşi depolama yöntemi ile toplanan katı atıkların ayrıştırılarak geri dönüştürülmesi ve ekonomiye kazandırılması günümüzde mümkündür. Yerel yönetimlerce benimsenmesi gereken bu yaklaşım iklim ve deprem perspektiflerinden de desteklenmektedir. Atıkların ayrıştırılarak geri dönüşümünün yapılması kentsel toprak ve su kaynaklarının korunmasını sağlayabileceği gibi çöp gazı yakalama gibi iklim dostu stratejilerin geliştirilmesine de olanak sağlamaktadır. Kentsel atıkların sürdürülebilir bir sistem ile düzenlenmesi, deprem sonrasında oluşabilecek kentsel hizmet sunumunun aksamamasına katkı verecektir. Aksi halde, su yönetiminde olduğu gibi deprem sonrasında ciddi sağlık sorunları doğabilir (Lemonick, 20l I).

Kentsel enerji altyapısı, ağırlıklı olarak elektrik ve doğalgaz sunumu üzerine kurulu ve toplumun gelişmişlik düzeyinin artmasıyla daha çok kullanma ihtiyacı duyduğu sistemleri barındırmaktadır. Sanayileşme ile birlikte artan enerji tüketimi kentlerin elektrik üreten santrallere bağımlığını arttırmaktadır. Enerji kaynakları olarak, fosil yakıtların, termik santrallerin, hidroelektriğin kullanılması doğal çevrenin tahribatına ve kaynakların tüketilmesine yol açmaktadır. Değişen iklim koşullarında, yenilenemeyen bu kaynakların kullanılması krizi daha da tetikleyen bir faktördür. Bu nedenle, kentsel altyapı planlamasında enerji ihtiyacını karşılamak üzere güneş, rüzgar, dalga, jeotermal ve biyokütle gibi yenilenebilir enerji sistemlerini önceleyen stratejilere yer verilmelidir. Fosil yakıt tüketimine dayanan enerji üretim sistemleri barındırdıkları kesinti ve erişim riskleri nedeniyle deprem açısından da sürdürülebilir olmayan sistemlerdir. Kentsel ana altyapı şebekelerinden bağımsız, tekil olarak enerji üretebilecek yenilenebilir enerji sistemlerine kent planlarında yer verilmesi, deprem hasarlarından kaynaklı risklerin bertaraf edilmesini sağlayacaktır.

Sanayi toplumundan bilgi toplumuna geçişle birlikte, haberleşme, iletişim ve bilişim sistemlerinin su ve enerji gibi yaşamsal fonksiyonlardan biri haline geldiği açıtıtır. İletişim araçları ve bilişim teknolojileri, iklim ve deprem konularını bütünleşik olarak ele alan planlama süreçlerinin, hazırlık, uygulama ve izleme aşamalarında fayda sağlayacak akıllı araçlar sunmaktadır. $\mathrm{Bu}$ araçlar, kentlerde karbon emisyonlarının izlenmesi, yağış hacimlerinin değişimi, ısı adalarının ölçülmesine katkı verebileceği gibi; bu sistemlerin sunduğu teknolojilerden, deprem 
esnasında müdahale edilecek alanların saptanması, kurtarma ekiplerinin yönlendirilmesi ve hasar tespitinin yapılması çalışmalarında da yararlanılabilir.

\subsection{Mahalle Ölçeği Kapsamındaki Strateji Alanları}

\subsection{Alt Ulaşım Sistemleri ve Sokaklar}

Kent merkezi ile çevresindeki kent parçalarını bağlayan alt ulaşım sistemleri Nazım ve Uygulama İmar Planlarıyla belirlenir. Uygulama İmar Planlarında belirlenen alt kademe yol genişlikleri her kent için standart olmayıp, özellikle deprem riskli yüksek olan kentlerde standartların üstünde tasarlanmalıdır. Yol sistemi tasarlanırken, kentin merkezine, hizmet odaklarına ve afet bağlamında kritik tesislere ulaşımı sağlayan alt sistemler tekil yol bağlantıları yerine çoklu bağlantılarla desteklenmelidir. Çoklu bağlantılar, alternatif ulaşım olanağı sağlayacak düzenlemeler ile olası acil durum ortamında oluşan yoğunluğun dengeli bir şekilde dağılmasını sağlar. Çoklu ulaşım alternatiflerini benimseyen deprem odaklı yaklaşım, karbon salımı ve asfalt yüzeyin artması nedeniyle iklim açısından çatışma yaratmaktadır. Öte yandan, özellikle tarihi kentsel dokularda ve merkezlerde görülen tek yön araç trafiği düzenlemeleri, iklim krizi ve deprem açısından ortak bir sorun alanı olarak kabul edilebilir. Bu yollar, erişilebillirliği kısıtlayıcı ve dolaşım mesafelerini uzatan nitelikleri ile bir yandan enerji tüketimini ve karbon salımını artıracağı gibi, diğer yandan acil durum anında toplanma, tahliye ve müdahaleyi güçleştirecektir.

Mahalle ölçeğinde okul, sağlık ocağı vb. kamusal kullanımlar ve konut alanları arasında motorlu taşıtlarla kısıtlanmayacak şekilde, yaya ve motorsuz araçlara öncelik veren düzenlemeler enerji kullanımı ve kirlilik azaltımı açısından önemlidir. Benzer şekilde, kent alt sistemlerinde acil bir durumda hızlı tahliye gerçekleşmesi için yaya öncelikli düzenlemelere ihtiyaç vardır. Deprem riskleri gözetildiğinde, çocuklar, engelliler, yaşlılar, hamileler gibi özel gereksinimli kullanıcılar için ulaşılabilirliği kolaylaştırıcı tasarımlar da imar planlarıyla düzenlenmelidir.

\subsubsection{Açık ve Yeşil Alanlar}

Kentsel açık alan sisteminin en küçük birimleri mahalle ölçeğinde yer alan, kamusal açık alanlardır. Bu alanlar, mahalle parkları, çocuk parkları, oyun alanları, spor sahaları gibi mahalle yaşamına hizmet edecek farklı kullanım biçimlerine ayrılabilir (Kalabalık, 2017). Günlük hayatta fiziksel aktivitenin yapılabildiği, sosyalleşmeye olanak sağlayan ve doğal parçaların yer aldığı açık alanlar, yapılı çevre içinde dolu-boş dengesinin kurulmasını sağlar. Bu denge kurulumunda, açık alanların imar planlarıyla tasarlanması iklim ve depreme yönelik harekete geçmek için olanak sunan unsurlardır. İklim ve depremi bir arada ele alan planlama yaklaşımında, açık alanların büyüklüklerini belirleyecek olan standartlar, mevzuatın gerektirdiği asgari standartlar ve büyüklüklerin daha üzerinde ele alınabilir ve işlevleri de yere özgü risklere göre belirlenmelidir.
Açık alan kullanımları, farklı işlevler için tahsis edilse de, deprem açısından insanların bir araya gelmesi ve acil durumda ilk erişilebilecek alanlar olarak hizmet edecektir. Bu alanlar, öncelikle deprem esnasında kolay erişilebilecek, yürüme mesafesi içinde ve her komşuluk kümesine adil hizmet verebilecek şekilde konumlanmalıdır (French vd., 2019). Deprem esnasında, bu alanların, başta özel gereksinim duyanlar olmak üzere, bireylerin kolay hareket etmesini sağlayacak sert zeminle örtülü olması tercih edilir. Ancak, toprak yüzeyini kapatan bu durum iklim krizi açısından bakıldığında çatışma yaratır niteliktedir. Benzer şekilde, bu alanlarda yer alacak ağaçlar mikroklimatik etki açısından iklim krizine uyum bağlamında olumlu birer bileşen olacakken, bu açık alanların tamamının ağaçlandırılması deprem sonrası toplanmayı zorlaştıracaktır. Bu nedenle, mahalle ölçeğindeki açık alanlar tasarlanırken, yüzey örtüsü dengesi göz önünde bulundurulmalıdır.

Açık alanlarda, yerel iklim koşullarına uygun peyzaj kararları ile termal konforun sağlandığı nefes alma alanları oluşturulabileceği gibi, doğru zemin malzemesi ve bitki örtüsü ile yüzey geçirgenliği kontrol edilerek peyzaj bakımı için tüketilen su miktarı da azaltılabilir (Peker ve Aydın, 2019). Örneğin, bu tür açık alanlarda çim yerine yonca gibi bakımı için daha az su tüketen ve yüzeyde daha az su biriktiren zemin örtüsü tercih edilebilir.

\subsubsection{Yapı Düzeni/Nizamı}

İmar planlarında bölünen yapı adaları içerisindeki yapılaşma düzeni, Uygulama İmar Planları kapsamında bulunan yapı düzeni kodları ile belirlenir. Yapı düzeni kararı arazi koşullarına, üst ölçekte verilmiş arazi kullanım kararına ve nüfus yoğunluğuna göre verilir. Bu ölçekte üretilecek kentsel dokular kent bütünündeki yaklaşımın ve makroformun bir parçası olarak ele alınır.

Çevrenin bitişik ya da ayrık yapı nizamıyla geliştirilmesi, deprem riskleri açısından önemli rol oynamaktadır. Özellikle, zemin koşularının zayıf olduğu kentlerde, yüksek katlı bitişik nizam yapılaşma tipi yapıların göstereceği farklı esneme kabiliyetlerinden dolayı depremden doğacak fiziki hasar riskini artırabilir. Bitişik nizamda cephe genişliği daha fazla olan bina çekiçleme etkisi yaratarak dar cepheli bir yapıyı devirebilir (IBB, 2000).

Yapı düzeni aynı zamanda sokak oluşumlarının temel belirleyicisidir. Bu yönüyle sadece yapılı alanları değil, dış mekân kullanımlarını da etkiler. Örneğin, sıcak iklim kuşaklarında yer alan kentlerde bitişik nizam yapı düzeni ile kesintisiz gölgelendirme yaratılarak konforlu bir yaya sirkülasyonu sunan bir sokak düzeni elde edilebilirken, soğuk kuşaklardaki kentlerde istenmeyen rüzgar koridorlarından kaçınmak için ayrık yapı nizamı tercih edilebilir (Peker ve Aydın, 2019). Ancak, yapı nizamı kararı diğer tasarım kararları ile beraber düşünüldü- 
ğünde etkin bir hal alır. Konforun yanı sıra, yapı düzeni yapılı çevredeki enerji tüketim kalıplarını da etkiler. Yapı ölçeğinde, bitişik veya ayrık nizam konutlarda ısıtma ve soğutma amaçlı enerji tüketim değerleri farklılık gösterecektir. Sokak düzeyinde ise, yapılaşma düzeni ile oluşan yaya konforu yürünebilirliği teşvik ederek motorlu taşıt kullanımı ve beraberindeki fosil yakıt tüketimini azaltacaktır.

\subsubsection{Yapı Yoğunluğu (TAKS/KAKS)}

Parsel boyutları, taban ve inşaat alanı, kat yükseklikleri, çekme mesafeleri gibi yapılaşma ilkeleri I/I.000 ölçekli Uygulama İmar Planı ile belirlenir. Bu ölçülerin tespitinde deprem riskleri gözetilirken yerel iklim koşulları da dikkate alınmalıdır. Parsel büyüklüğü dahilinde verilecek taban alanı ve inşaat alanı büyüklükleri ve buna bağlı olarak kat yüksekliği, yapının depreme karşı dayanıklılı̆ının ve enerji verimliliğinin en temel belirleyicileridir. Geçmişte ülkemizde yaşanan depremler, yapılardaki cephe genişliği ve yüksekliği arasındaki uyumsuzluklar, dar cepheli parsellerde yapılaşma, ikiz nizam dar cepheli bodrumsuz çok katlı yapılar, bina yüksekliği ile temel derinliği oranındaki uyumsuzluklar, zemin kat dükkan yüksekliğinin fazla olması gibi faktörlerin yapının göstereceği sismik performansı düşürdüğünü ve yıkım ile sonuçlandığını göstermektedir (IBB, 2000). Bu faktörler deprem esnasında yapının göstereceği performansın yanı sıra depremden sonra yapı ve açık alanlar ilişkisini de belirleyecektir. Yapısal hasar ve yıkılmalar sonucu sokak, cadde ve açık alanların kullanılabilirliği de yapı ile sokak arasındaki mesafeye bağlıdır. Yapının sokak ile mesafesi, deprem sonrası trafik akışının devamlılığı açısından oldukça önemlidir.

Yapıların ön, arka ve yan bahçe mesafeleri, aynı zamanda, mahalle ölçeğinde nefes alma alanları olarak tarif edilen kent içi boşlukların oluşmasında belirleyici bir role sahiptir. Parsel cepheleri yapı nizamı ile birlikte sokak dokusunu ve sokaktaki gök görüş faktörünü tanımlar. Örneğin, bitişik nizam ve ön bahçe çekme mesafesi dar olan yüksek katlı bir yapı dizisi, düşük gök görüş faktörüne sahip dar kentsel kanyonlar oluşturacaktır. Bu durum, soğuk ve karasal iklimlerde binalarda güneş ışınımından faydalanmayı azaltacağı için ısınmada enerji tüketiminin artmasına neden olacaktır. Bu bağlamda, yapı yoğunluğu belirlenirken cephe, taban alanı ve yükseklik oranlarının her iki koşul açısından avantaj yaratacak şekilde düşünülmelidir.

\subsection{Yapı Ölçeği Kapsamındaki Strateji Alanları}

\subsection{Yapı Kullanım Türü}

Nazım İmar Planı ile belirlenen arazi kullanım türlerine uygun parsel kullanım fonksiyonları I/I.000 ölçekli Uygulama İmar Planı ile şekillendirilir. Ada bazında belirlenen, konut, ticaret, sanayi, park, rekreasyon, spor, karma kullanım, sosyal tesis ve ibadet gibi farklı kullanım tipleri, farklı yapı tasarımını gerektirmektedir. Deprem riski açısından, kamusal kullanımların ve kullanıcı sayısının yüksek olduğu yapılar için erişilebilirlik, açık alanlar ve yapı nizamı konuları birlikte düşünülmelidir. Bunların dışında, konut ve ticaret kullanımlarının bir arada yer aldığı karma kullanımlı yapılarda ise, her iki kullanıma cevap verebilecek alan büyüklükleri yaratılırken, yapının tasarımının deprem riskini gözetmesi gerekmektedir. Örneğin, zemin katında ticari kullanım olan bir konut ünitesinde zemin kat yüksekliği, zemin kat üstü çıkmaları ve ticaret için ayrılan fonksiyonlar yapının deprem performansını etkileyecek değişkenlerdir.

Yapı kullanım türü enerji tüketim kalıplarının da belirleyicisidir. Bu bağlamda, kullanım türleri ve tüketim yoğunluklarına göre yenilenebilir enerji kaynaklarından yararlanma stratejileri geliştirilebilir. Özellikle eğitim, sağlık, spor ve idari kullanımlı kamusal yapılarda bu sistemlerin kurulması ve işletilmesi yerel yönetimlerce daha hızlı uygulanabilir niteliktedir. Konut kullanımı gibi bireysel tüketimin daha yüksek olduğu yapılarda ise, üst ölçekte farklı kurumlar ile işbirliği içerisinde geliştirilecek teşvik mekanizmaları ile bunu sağlamak mümkündür.

\subsubsection{Yapı Tasarımı}

Yapı formu, cephesi, çatı, pencere gibi açıklıklar ve yapısal elemanlar yapı tasarımını ilgilendiren konular arasında olup Uygulama İmar Planı kapsamında ele alınmalıdır. Yapı tasarımındaki elemanlar, yerel iklim koşullarından faydalanmanın yanı sıra yapının bulunduğu alanın depremselliği de göz önüne alarak belirlenmelidir. Deprem bakımından, sismik riske karşı binaların dayanımını artırmak üzere arazi koşullarına ve yapı koşullarına uygun yapı tasarımı çözümleri yapılır. Yapı formunda, cepheyi oluşturan çıkmalar, bitişik nizamdaki kolon-kiriş ilişkileri, taban alanı ve zemin kat genişliği gibi konular riskli alanlarda yapı tasarımının temel ögeleri olarak sayılabilir. Bina cephesinin dışına taşarak çıkıntı teşkil eden kolanlar sarsıntıya karşı yeterli dayanımı gösteremeyip yapının hasar almasına neden olabilir (IBB, 2000). Benzer şekilde, dayanıksız balkon çıkmaları ve çatı saçaklarında kırılmalar meydana gelebilir. Yüksek katlı bloklarda ise tabandan çatıya genişleyerek yükselen formlar dayanıklılığı azaltacaktır, bu nedenle, deprem riski yüksek alanlarda, yapıların sismik performansını arttırmak için daralan formlar tercih edilmelidir.

Yapı formunun tasarımı, iklim krizi bağlamında enerji verimliliğini sağlamak için de bir fırsat olarak değerlendirilebilir. Yerel koşullara uygun yapı formu, yönlenmeler ve peyzaj düzenlemeleri ısınma-soğutma amaçlı yakıt tüketimini azaltmak üzere güneş, rüzgar, nem gibi tüm iklim kriterlerini dikkate almalıdır. $\mathrm{Bu}$ noktada, çatı ve pencere tasarımları, cephede oluşacak açıklıklarda ve dolayısıyla olası ısı kayıplarında oynadıkları belirleyici rol ile enerji tüketimini etkiler. Bunun yanında, mimari proje ve sistem detayları düşünülürken doğal kaynaklardan yararlanan akıllı sistem tasarımlarından da faydalanılabilir. Metrekare başına düşen yağış miktarları artan bir iklim kuşağında, farklı kademelerde (çatı, teras, zemin vb.) yağmur suyu topla- 


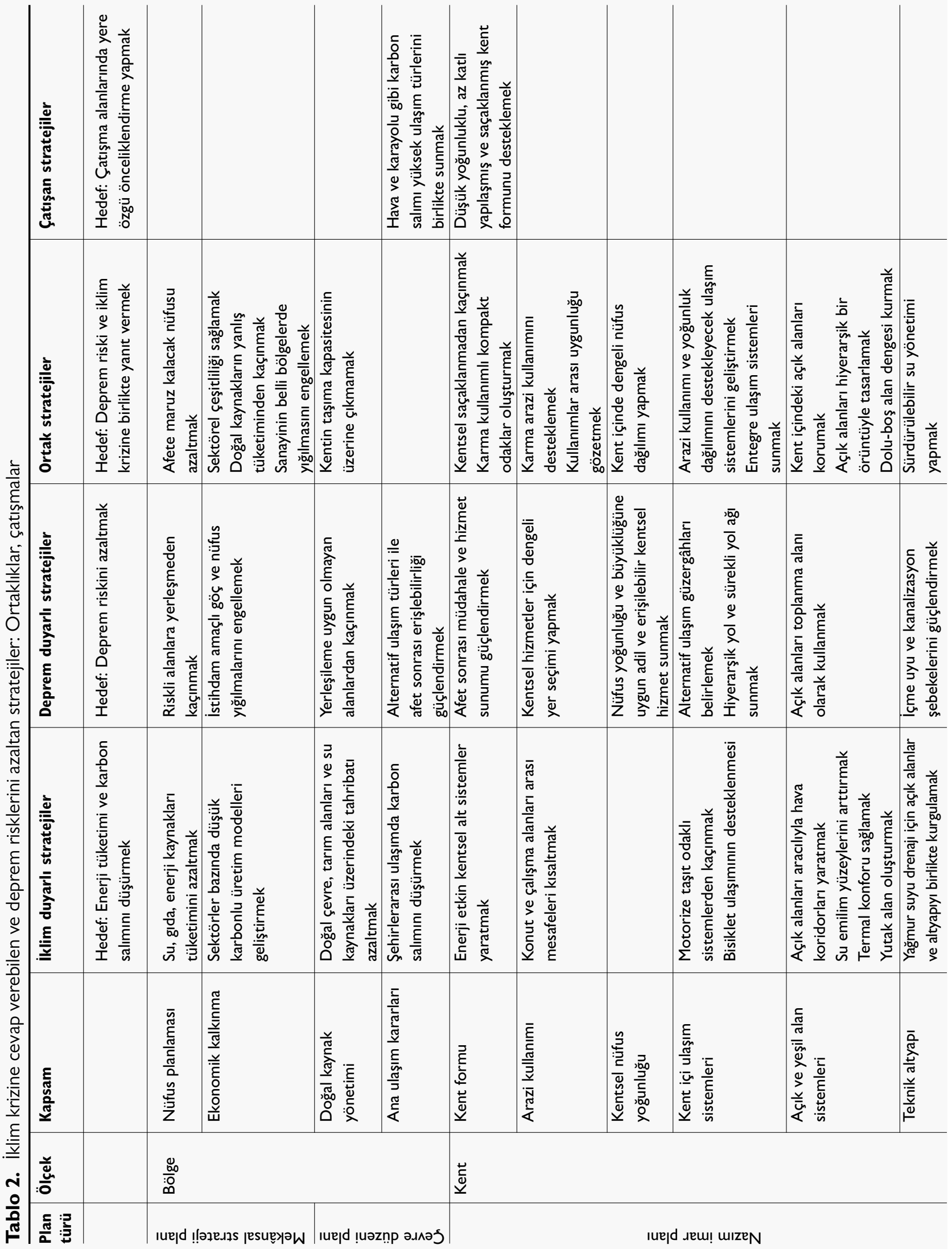




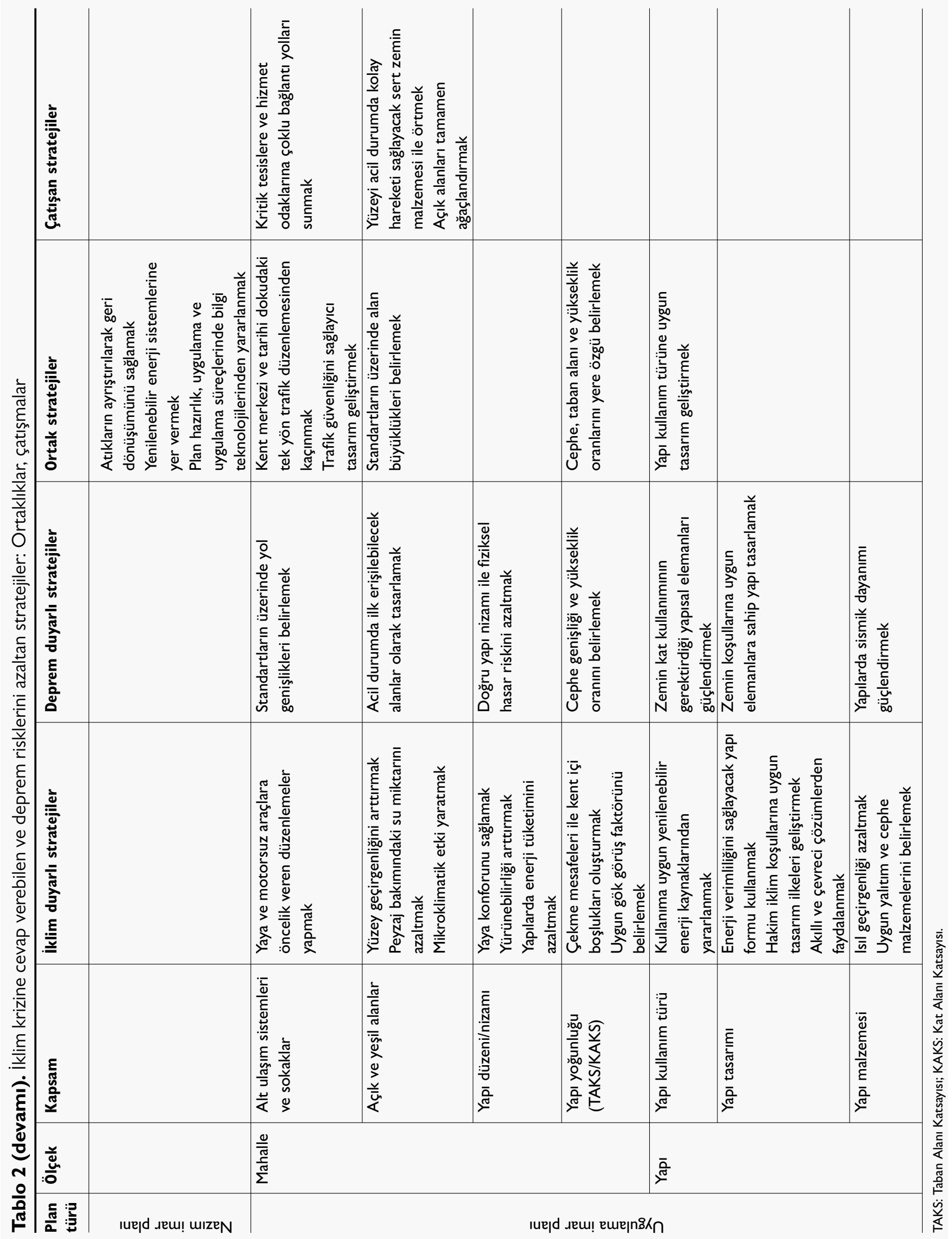


ma, depolama, arıtma ve kullanma sistemleri ile su kaynağı yaratmak etkin bir uyum stratejisi olabilir. Benzer şekilde, çatı ve cephelerde kullanılacak güneş panelleri ile üretilecek enerji, binaların ve suyun ısıtılmasında kullanılabilir.

\subsubsection{Yapı Malzemesi}

Uygulama İmar Planlarında, yapı malzemelerine yönelik seçimler ve ilkeler plan notları ile tarif edilebilir. Malzeme detayları, deprem ve iklim riski gözetilerek belirlenmeli ve plan notlarında yönlendirici nitelikte yer almalıdır. Deprem riski açısından, betonarme, çelik, hafif çelik, yığma ve ahşap malzemeden yapılan binalara yönelik kararlar, Uygulama İmar Planlarında yapının ve yapılı çevrenin durumuna göre ilgili yönetmeliklere referansla ele alınır. Ayrıca, yapılı çevredeki yapıların koşullarına göre gerekli politikalar geliştirilebilir. Sismik dayanımı güçlü malzeme ve statiğe sahip yapılarda koruma, bu açılardan daha zayıf olan yapılarda güçlendirme, zemin ve yapı açısından en zayıf durumda olan yapılı çevrede ise topyekûn kentsel dönüşüm ile yeniden inşa etme yöntemleri uygulanabilir.

İklim açısından ise, yapı malzemelerinde dikkate alınması gereken en temel konu ısıtma ve soğutma kaynaklı enerji tüketimi ile ilişkin yapı tabakalarının ısıl geçirgenliği, yalıtım ve cephe malzemeleri tercihidir (Krope ve Goricanec, 2009; Milne ve Givoni, 1979). Farklı iklim kuşaklarındaki kentlerde binaların ısı tutan veya kaybeden yüzeylerindeki duvarlar, tavan ve tabanda kullanılan döşemeler ve malzemelerin kalınlıkları ihtiyaca yönelik çeşitlendirilmelidir.

\section{Sonuç}

İklim krizi ve deprem risklerine hazırlıklı olmada küresel ölçekteki örgütlenmeler, protokoller ve anlaşmalarla başlayan hareketler, günümüzde ulusal, bölgeler ve yerel ölçekte aktif eylemlerle yürütülmesi beklenen bir hale gelmiştir. Bu bağlamda, merkezi ve yerel yönetimlerin sorumluluk alarak, yere özgü somut adımları tanımlaması ve yenilikçi uygulamaları devreye sokması beklenmektedir. Ülkemizde, her ne kadar iklim ve depreme dair uluslararası anlaşmaların bir kısmına taraf olunmuş ve bu doğrultuda ulusal eylem planları hazırlanmış olsa da, bu çerçevenin ulusal, bölgesel ve yerel ölçeklerdeki uygulamalarda nasıl yer bulacağı konusu muğlaktır. Hâlbuki, bu konuların gerektirdiği farklı ölçeklerdeki adımların büyük bir kısmının mekânsal planlama aracılığıyla gerçekleşme imkanı vardır.

Bu çalışma ile, iklim ve deprem konularına duyarlı bütüncül bir planlama yaklaşımının geliştirmesi için planlama ilkelerine ortak girdi yapabilecek hiyerarşik bir çözüm önerisi seti geliştirilmiştir. Bunun için, çalışmada geliştirilen yöntem doğrultusunda, Mekânsal Planlar Yapım Yönetmeliği'nde tanımlanan plan kapsamları ve ulusal eylem planlarında tanımlanan mekânsal stratejik alanlara göre belirlenmiş plan alt temaları ortaklaştırılmış ve dört kavramsal ölçekte her bir alt temaya ilişkin stratejiler ortaya konmuştur. Tablo 2, tüm öneri setini, ortaklaşan ve çatışma yaratan alanları özetlemektedir. Buna göre, farklı ölçek ve konulardaki iklim ve deprem stratejilerinin büyük oranda birbirini desteklediği ve etkileşim yaratarak daha etkin çözümler sunabileceği görülmektedir. Öte yandan, bu stratejiler içinde konu özelindeki özgün müdahalelerin sınırlı da olsa bir diğeriyle çatışma yarattığı alanlar da bulunmaktadır. Bu gibi çatışma durumlarında, karar vericilerin yere özgü koşulları göz önünde bulundurarak önceliklendirme yapması beklenmektedir. Burada vurgulanması gereken bir diğer husus, sunulan konu başlıklarının birbirinden bağımsız üretilmediği ve farklı ölçekler arasında verilen kararlar arasında bir etkileşim olduğudur. Örneğin, kent formu, tek bir karara bağlı olarak belirlenen bir değişken değil, ulaşım sistemleri, yapı düzenleri, mahalle oluşumları gibi farklı kentsel değişkenler ve hatta bölgesel düzeydeki plan kararlarıyla da şekillenen ve zaman içinde farklılaşan bir değişkendir. Dolayısıyla, Tablo 2'nin sunduğu sinerji ve çatışma alanları bir kontrol listesi oluşturmaktan ziyade, birlikte ele alınabilecek konu başlılarını özetlemektedir.

Sonuç olarak, bu çalışma, mevcut planlama sistemi içinde, mekânsal planlar yapım süreçlerine bağlı kalarak, deprem ve iklim değişikliği kaynaklı afetler için bütüncül bir planlama perspektifinin geliştirilebileceğini göstermiştir. Bütüncül bir yaklaşım, bilimsel bilginin yanı sıra, sosyal ve teknik konuları kapsayan uygulama bilgisinin üretildiği ve tüm bu üretime tabandan örgütlenen ilgili aktör gruplarının dahil edildiği bir süreç tasarımı gerektirmektedir (Ataöv ve Peker, 202I). Böyle bir yaklaşımın ilk katkısı, konular özelinde üretilen bilimsel bilginin ve uluslararası örgütlerin belirlediği ilkelerin yere özgü değişkenler ile harmanlanmasını sağlayarak, yerelde işleyen çözümlerin bulunması olacaktır. İkinci olarak, deprem ve iklim konularında sorumluluk alacak uygulayıcıların bu politikalara tekil çözümler üretmeleri yerine, bir bütün olarak bakabilmeleri ve kapsamlı çözümler geliştirebilmelerine olanak verecektir. Son olarak, bütüncül bir planlama yaklaşımı, pek çok konu alanı ile ilişki kuran deprem ve iklim eylemlerinin ilgili aktörlerini bir araya getirerek birlikte çalışmalarına bir zemin hazırlayacaktır.

Çalışmanın sunduğu perspektiften yola çıkarak, gelecek çaışmalarla desteklenebilecek üç araştırma alanı bulunmaktadır. Bu çalışmanın kurduğu sistematikte geliştirilen öneri setinin, yönetmelik ve tebliğler düzeyinde yapılacak kapsamIı bir analiz ile mevzuata nasıl girdi yapacağı belirlenebilir. Çalışmada sunulan çerçeve, kıyı planlaması, koruma amaçlı imar planları gibi özel çalışma alanlarına genişletilebilir. Son olarak, burada ele alınmış deprem ve iklim değişikliği odaklı bütünleşik yaklaşım, farklı tehlike türlerinin kapsandığı daha geniş bir afet perspektifinden bakılarak yeniden ele alınabilir. 


\section{KAYNAKLAR}

AİGM (1997) Coğrafi Bilgi Sistemleri ile Deprem Bölgelerinin İncelenmesi, Bayındırlık ve İskan Bakanlığı Afer İşleri Genel Müdürlüğü Yayınları, Ankara.

Andong, R. F., and Sajor, E. (2017). Urban sprawl, public transport, and increasing CO 2 emissions: The case of Metro Manila, Philippines. Environment, Development and Sustainability, 19(1), 99-123.

Ataöv, A. \& Peker, E. (2021). Co-designing local climate action: A methodological framework from a democratic perspective. In E. Peker ve A. Ataöv. Governance of climate responsive cities: Exploring cross-scale dynamics, 147-164, Springer Nature: Switzerland.

Balamir, M. (2018) Afetler, Risk Yönetimi ve Sakınım Planlaması: Açıklamalı Kavram ve Tehditler, ŞPO Yayınları, Berk Matbaacılık: Ankara.

Berke, P., Beatley, T. and Wilhite, S. (1989). Influences on local adoption of planning measures for earthquake hazard mitigation. International Journal of Mass Emergencies and Disasters, 7(1), 33-56.

Blaikie, P., Cannon, T., Davis, I., and Wisner, B. (2014). At risk: natural hazards, people's vulnerability and disasters. Routledge.

Burby, R. J., Beatley, T., Berke, P. R., Deyle, R. E., French, S. P., Godschalk, D. R., May, P., Olshansky, R. and Paterson, R. G. (1999) Unleashing the power of planning to create disaster-resistant communities. Journal of the American Planning Association, 65(3), 247-258.

Burby, R. J., \& Dalton, L. C. (1994). Plans can matter! The role of land use plans and state planning mandates in limiting the development of hazardous areas. Public Administration Review, 54(3), 229-238.

ÇŞB (2010) KENTGES - Bütünleşik Kentsel Gelişme Stratejisi ve Eylem Planı 2010-2023, ÇŞB Yayınları: Ankara.

Elbir, T. (2008). Estimation of engine emissions from commercial aircraft at a midsized Turkish airport. Journal of Environmental Engineering, 134(3), 210-215.

Erdik, M. (2000). Report on 1999 Kocaeli and Düzce (Turkey) earthquakes. Boğaziçi Üniversitesi, Kandilli Rasathanesi ve Deprem Araştirma Enstitüsü.

Faisal, I. M. \& Parveen, S. (2004) Food Security in the Face of Climate Change, Population Growth, and Resource Constraints: Implications for Bangladesh, Environmental Management 34, 487-498.

French, E. L., Birchall, S. J., Landman, K., \& Brown, R. D. (2019). Designing public open space to support seismic resilience: A systematic review. International Journal of Disaster Risk Reduction, 34, 1-10.

Gedikli, B. (2020) Sürdürülebilir ve İklime Duyarlı Kentler İçin Planlama ve Tasarımda Yeşil Altyapının Rolü, KBAM 7. Sempozyumu Bildiriler Kitabi, Ankara, 61-91.

Giorgi, F. \& Lionello, P. (2008) Climate change projections for the Mediterranean region, Global and Planetary Change (63), 90-104.

IBB (2000) Deprem kuvvetleri karşısında yapıların gösterdiği davranışlar, İBB KIPTAŞ yayınları: İstanbul

IPCC (2007) Climate Change 2007: Impacts, Adaptation and Vulnerability. Contribution of Working Group II to the Fourth Assessment Report of the Intergovernmental Panel on Climate Change, M.L. Parry, O.F. Canziani, J.P. Palutikof, P.J. van der Linden and C.E. Hanson, Eds., Cambridge University Press, Cambridge, UK, 976.

Kalabalık, H. (2017) İmar Hukuku Dersleri, Seçkin Yayıncllı, Ankara.

Kesgin, U. (2006). Aircraft emissions at Turkish airports. Energy, 31(2-3), 372-384.

Krope, J. \& Goricanec, D. (2009). Energy Efficiency and Thermal Envelope, In D. M. a. M. Santamouris (Ed.), A Handbook of Sustainable Building Design and Engineering London: Earthscan Publishing.

Lelieveld, J., Hadjinicolaou, P., Kostopoulou, E., Chenoweth, J., El Maayar, M., C. Giannakopoulos, C., Hannides, C., Lange, M. A., Tanarhte, M., Tyrlis, E. \& Xoplaki, E. (2012) Climate change and impacts in the eastern mediterranean and the Middle East, Climatic Change, 114, 667-687.
Lemonick, D. M. (2011). Epidemics after natural disasters. American Journal of Clinical Medicine, 8(3), 144-152.

Littlefair, P.J. (2000). Environmental site layout planning: solar access, microclimate and passive cooling in urban areas. BRE publications.

Marshall, J. D. (2008). Energy-efficient urban form, Environmental Science \& Technology 42, 9, 3133-3137.

Milne, M. \& Givoni, B. (1979). Architectural Design Based on Climate In D. Watson (Ed.), Energy Conservation Through Building Design USA McGraw-Hill.

Mitchell, G., Hargreaves, A., Namdeo, A. \& Echenique, M. (2011) Land use, transport, and carbon futures: the impact of spatial form strategies in three UK urban regions, Environment and Planning A, 43, 2143-2163.

Orhan, E. (2014). The role of lifeline losses in business continuity in the case of Adapazari, Turkey. Environmental Hazards, 13(4), 298-312.

Orhan, E. (2016). Building community resilience: business preparedness lessons in the case of Adapazar1, Turkey. Disasters, 40(1), 45-64.

Peker, E. (2021) Bir şehircilik problemi: Değişen iklimde termal konforu sağlamak. Planlama 2021,31(1):108-119.10.14744/planlama.2020.92679

Peker, E. \& Aydın, C. İ. (2019) Değișen iklimde kentler: yerel yönetimler için azaltim ve uyum politikaları, Mercator-IPM Politika Notu, İstanbul Politikalar Merkezi.

Stone, B., Hess, J. J. \& Frumkin, H. (2010) Urban Form and Extreme Heat Events: Are Sprawling Cities More Vulnerable to Climate Change Than Compact Cities? Environmental Health Perspectives 118(10), 1425-28.

Trubka, R., Newman, P. \& Bilsborough, D. (2010) The Costs of Urban Sprawl - Predicting Transport Greenhouse Gases From Urban Form Parameters, Environment Design Guide, GEN 84, 1-16.

Turral, H., Burke, J. \& Faurès, J. M. (2011) Climate change, water and food security. Water Reports No.36, 1-174.

Vörösmarty, C. J., Green, P., Salisbury, J., \& Lammers, R. B. (2000). Global water resources: vulnerability from climate change and population growth. Science, 289(5477), 284-288.

Wisner, B. (2003). Disaster risk reduction in megacities: making the most of human and social capital. Building safer cities: The future of disaster risk, 181-96.

Xiao, Y. \& Drucker, J. (2013). Does economic diversity enhance regional disaster resilience?. Journal of the American Planning Association, 79(2), $148-160$ 